papers and books by Shannon, by Norbert Wiener and by others, which make rather difficult reading for the non-mathematician, must have the uneasy feeling that they are missing something important. They will be much relieved if they read a short paper by Dr. P. M. Woodward, in the May issue of the British Journal of Applied Physics. There they will find that, so far as the non-specialist is concerned, the subject is one the essentials of which can be lucidly and comprehensively dealt with in a few pages. The paper will interest a very wide range of readers.

\section{Postgraduate Engineering Production Courses in the University of Birmingham}

A NOTE on developments in engineering production and management studies, contributed by Prof. T. U. Matthew to the University of Birmingham Gazette (5, No. 4; 1953), refers to the increasing tendency of graduates in engineering to return to the University after four or five years in industry ; and the Birmingham postgraduate diploma course of studies in the principles of engineering production management has been designed to meet the needs of such men who wish to fit themselves for the task of devising and introducing improved products and manufacturing methods, and for subsequent executive posts in production development or administration. During the past four years, fifty graduates have taken this course, and the current group of seventeen graduates includes five from overseas. The Department has also conducted short residential summer schools at Primrose Hill which have been attended during the past four years by more than a hundred and fifty senior managers and production engineers. The Department now plans to provide throughout the year a continuing series of short residential courses of the $\operatorname{sam} \theta$ nature, and the firm of Joseph Lucas, Litd., has provided $£ 57,400$ for the purchase and equipment of a large house for use as a residential centre. Prof. Matthew believes that the University can play an important part in modern industrial society by providing educational courses and research facilities which bear directly on the problems of increasing industrial productivity and of strengthening the national economy. The major aim of the Department is to carry out scientific investigation on the main lines of study in the graduate courses, and this will be realized more fully when accommodation in the engineering buildings at Edgbaston becomes available next year. Meanwhile, grants from the Department of Scientific and Industrial Research and the Tube Investments Research Fellowship have greatly assisted research on work measurement and job evaluation, the variations in human muscular force, the output variation in repetitive tasks, the nature and acquisition of industrial skills, and the organization and use of scientific and technical information in Midland industries.

International Commission on Illumination (C.I.E.) : Meeting of Technical Committee on Daylight

AT the sessional conference of the International Commission on Illumination (C.I.E.) at Stockholm in 1951, it was agreed to hold a special meeting of the Technical Committee on Daylight in 1953 to discuss developments in the subject which were incomplete at the time. This meeting was held, during May 6-9, 1953, at the Abbaye de Royaumont, Creil, near Paris. Delegates from seven countries attended. The arrangements for the meeting were undertaken, on behalf of Australia which was unable to send a delegate, by the British delegation. Papers were presented describing recent work on the distribution of sky brightness, inter-reflexion of light in rooms, total solar radiation, and the systematic control of reflected sunlight in relation to building design in sunny climates. New instruments for the measurement of daylight factor, for the calculation of total daylight factor in rooms, and for the study of nebulosity were shown. An interesting feature of the conference was the apparently closer co-operation between physicist and architect in Britain, Australia and the United States than on the Continent. From the Continent come ingenuity and precision in the study of natural lighting, while the former countries are concentrating on practical applications of the work to building design and the development of simple tools and instruments for the wider use of architects and lighting engineers. The C.I.E. meeting was preceded by a conference organized by the Association Française des Eclairagistes, at which were read summaries of recent work in France, Britain, Sweden and Germany prepared by M. Jean Dourgnon, Dr. R. G. Hopkinson, Mr. Gunnar Pleijel and Prof. W. Arndt, respectively.

\section{Conference on Nuclear Physics}

A CONFERENCE on nuclear physics is to be held in the University of Birmingham during July 13-18. Among the subjects to which sessions will be devoted are: low energy-levels and light nuclei; dense energy-levels and the statistical approach; study of the nucleus by high-energy processes; scattering of gamma-rays, angular correlations and conversion coefficients and oriented nuclei and polarized beams; experimental methods; and meson theory of nuclear forces. It is hoped to produce shortly after the Conference a set of notes, summarizing the discussions. About a hundred visitors from overseas and a similar number from universities in Great Britain are expected to be present.

Salters' Institute of Industrial Chemistry : Awards

ON the recommendation of the director, Sir Alfred Egerton, the Court of the Salters' Company has elected the following to be Salters' Fellows for the year 1953-54: W. A. Holmes-Walker; P. P. Manning. Mr. Holmes-Walker has been demonstrator and assistant lecturer in chemistry in Queen's University, Belfast, and has carried out research on the electric and magnetic properties of alkyl-organic compounds; he proposes to carry out research in the Department of Chemical Engineering at the Imperial College of Science and Technology, London, on highpressure techniques. Mr. Manning (Emmanuel College, Cambridge) has been carrying out research at Cambridge on the theory of molecular structure; he proposes to carry out research in experimental physical chemistry before entering chemical industry as a physical chemist. The Court of the Salters' Company has also elected the following to be Salters' Scholars for the year 1953-54: G. Hetherington, J. P. Howard, P. Kendrick, C. C. McCain and W. L. Wilkinson.

\section{British Memorial Fellowships, Victoria, Australia}

British Memorial Fund Fellowships of the State of Victoria, Australia, have been awarded for 1953, as follows: Agriculture, Miss Mary D. Thomas (University of Wales) ; Virology, N. P. L. Wildy (Gonville and Caius College, Cambridge); Natural Science, Dr. Madeline C. Walters (University of 